\title{
Canadian Sanctuary
}

\author{
by David Matas
}

What is the legal position of Canadians who help refugees come to Canada, enter Canada and stay in Canada? Are Canadians who help refugees breaking the law?

The act of helping refugees arrive, enter and stay may be a violation of the legislation. Whether it is breaking the law is less clear. To determine whether violating the legislation means breaking the law we cannot look only at the legislation in isolation. We must look as well at the Canadian Charter of Rights and Freedoms and international law.

We cannot assume that refusing to comply with the legislation amounts to civil disobedience. If the legislation violates the Charter and international law, then those who comply with the legislation are legally disobedient. Those who do not comply with the legislation and instead follow the requirements of the Charter and international law are legally obedient.

Under the old law there was no need for those who wanted to help refugees to contravene the legislation. Refugees could come to Canada. Canadians could assist them in their coming. Once refugees arrived they could make refugee claims. If they were refugees they could stay.

The new law changes all that. First of all, it becomes more difficult simply to get here. Airlines are put in the role of immigration officers, stopping people from getting on planes if they do not have proper documentation. If they do not stop refugees from flying to Canada, the airlines are heavily penalized. They will be vigilant to prevent refugees from arriving.

The new law also penalizes any Canadian who assists refugees coming to Canada. Technically the penalty is imposed on those who assist people who come to Canada without proper documentation. But, in reality, refugees do not have proper documentation, and will come within this provision.

There are three possibilities. A refugee can come from a country for which there is a visitor's visa requirement, and have a visa. A refugee can come from a country for which there is a visitor's visa requirement and not have a visa. Or a refugee can come from a country for which there is no visitor's requirement. In each, the law will be violated.

If a refugee comes from a country for which there is a visitor's visa requirement, and does not have a visa, the refugee will not have proper documents simply because he or she did not have a visitor's visa.

If the refugee comes from a country for which there is a visitor's visa requirement, and does have a visitor's visa, the law is violated all the same. The refugee has proper documentation, but it has been obtained by misrepresentation or fraud since a refugee is not considered a visitor. In order to get the visa, the refugee must have told the visa office that he was intending to visit, whereas, in fact, he was intending to stay.

Even if a refugee comes from a country for which there is no visa requirement, there will be a problem. For refugees are considered immigrants. Even though visitors from some countries do not need visas, immigrants from all countries need visas to come to Canada. So virtually every refugee either will not have proper documentation or will have committed an offence to get it. Virtually everyone aiding a refugee to come to Canada will be committing an offence.

In addition to the new penalties in Bill C-84, the old penalties in the old law assume added significance because of the change in refugee procedures made through Bill C-55. When a refugee comes from an intermediate country, the new law says he has to be sent back to that intermediate country without there being any individualized determination about the human rights record of that country, the country's respect for the Refugee Convention, whether or not the refugee can return to that country, or whether or not the refugee can make a refugee claim in that country.

A refugee may come to Canada from a country that will not accept him back, or if it does physically allow him to return, will allow a return solely for the purpose of sending him back to the original cotet? try of persecution, without the possibity of a refugee claim. Yet, according to $t$ new Canadian law, back he would go the same.

Those in Canada who want to assit: refugees have to ask themselves what they can do to help. They have to ask both what is their moral responsibility and what is their legal duty.

It is a dilemma that was faced by the Sanctuary movement in the U.S. The U.S. has a different legal structure from Canada for refugees. But the practical upshot is the same. Real refugees are returned by the U.S. government through intermediaries to the country of danger.

The Sanctuary movement helps refugees enter the country in a clandestine fashion. It offers them shelter, clothing and food in the United States. It has made public statements about its intentions and encouraged others to join. In March of 1982, Jim Corbett and reverend John Fife, both of Arizona, held a press conference in Tucson where they announced they would publicly violate the provisions of the U.S. Immigration and Nationality Act, provisions that prohibit bringing into the U.S., transporting, concealing, harbouring or shielding any alien.

While Canadian law does not have quite the same offences as U.S. law, either under the old law, or under the new, a refugee who enters Canada without reporting to an immigration officer is committing an offence. So is anyone who aids him.

A person who enters Canada by means of a material representation, for instance a person who obtains a visitor's visa, or authorization, by saying he intends to visit, when he is really a refugee, is guilty of an offence. So is anyone who aids him.

What is more, eligibility screening does not apply to these people. A refugee who reports to an immigration officer at a port of entry may be sent back to the intermediate country from which he came. A person who sneaks across the border, or lies to get entry as a visitor cannot, legally, be sent back to an intermedi- 
ate country from which he came. He may be prosecuted, but he cannot be put into eligibility screening. The law creates an incentive for violation.

Given that the law gives more protection to refugees who enter Canada illegally than those who do not, those concerned with the fate of refugees have to ask themselves whether they want to aid refugees in circumventing the application of eligibility screening.

They have to ask themselves whether they want to do what the Sanctuary movement in the U.S. has done. Do they want to give sanctuary and declare sanctuary? Do they want to set themselves on a course of violation with both the new laws and the old laws in order to protect refugees?

The moral dimension of the answer to that question I will leave for others to answer. I want to focus simply on answering that question from a legal point of view.

A preliminary legal question is, are the provisions that generate the offences themselves constitutional? If the safe third country rule, the requirement of return to intermediate countries, is a violation of the Charter, and held to be so by the courts, the impetus to violate the legislation to circumvent that rule disappears. However, whether that rule is a violation of the Charter is a large and separate question. The same can be said about whether the provision criminalizing aid to refugees is constitutional. For the purpose of what follows, I assume that both provisions are functioning parts of the legislation.

The first question that has to be asked is, if a Canadian helps a refugee enter Canada in violation of the legislation, will he or she be prosecuted? The answer to that is, in principle, that he or she should not be.

The Government of Canada has a dual responsibility. It has a responsibility to administer the laws of Parliament. When there is a violation, there is a duty to prosecute. While there is a prosecutional discretion, that discretion cannot be exercised so as never to prosecute all violations under a law. If that happens, the intent of Parliament is ignored.

The Government of Canada also has, however, a responsibility to comply with its international obligations. And one of those obligations is the Refugee Convention. One of the presumptions that applies, when interpreting legislation, is that legislation must be interpreted, if at all possible, 80 as to be consistent with international law and Canada's international obligations.

The Government of Canada, when applying its immigration law, must apply it, if at all possible, so as to be consistent with the Refugee Convention. What that means is not prosecuting those who protect refugees.

There is a rule of state responsibility, as drafted by the UN International Law Commission, that is relevant here. It is the rule that the conduct of a person not acting on behalf of the state shall not be considered as an act of the state.

\section{The law creates an incentive for violation.}

This rule is subject to an exception. The rule is without prejudice to the attribution to the state of any conduct related to that of the private person and which is to be considered as an act of the state.

The effect of the rule is that a Canadian private citizen acting in his private capacity cannot implicate Canada internationally. What the individual does, does not put Canada internationally at fault.

However, the exception to this rule means a state breaches its international obligations if it has taken a complaisant attitude to the individual's actions and shown complicity with it. A state is internationally responsible where it has not done everything on its power to prevent the wrongful act of the private individual.

If a state does not prevent its citizens from acting in conflict with an international obligation of the state, then the state is in breach not of that obligation, but of a more general obligation to prevent the wrongful act.

The converse of these propositions is also true. Just as a state must prevent its citizens from acting in conflict with an international obligation of the state, so must a state not prevent its citizens from acting in conformity with an international obligation of the state. A state breaches its international obligations if it takes on obstructive attitude to such an individual's action and shows opposition to it. A state is internationally responsible where it has done anything in its power to hinder the rightful act of the private individual.

If we assume that those that a Canadian Sanctuary movement would help are indeed refugees, then the Sanctuary movement, by giving the refugees sanctuary, is helping Canada conform to its international obligations towards refugees. The Canadian Government, by prosecuting the individuals who provide sanctuary, would be in violation of its international obligations. It would be obstructing individual action that would put it in compliance with the Refugee Convention.

However, just because in principle the Government of Canada should not prosecute those helping refugees, it does not mean it will not prosecute. On the contrary, we have to believe it will. The Government, after all, introduced and pushed through Parliament the legislation to give it the power to send back refugees to intermediate countries. It would be foolhardy to think it went to such pains to get this law simply in order to have it sit unused in the stature books. We have to presume that, in a situation where Canadians aid refugees to seek protection, in violation of the legislation, prosecutions will follow.

The question is: What will be the result of that prosecution? The presumption that Canadian law will be interpreted in conformity with international law is relevant on the question of conviction as well. If the person really is a refugee, if the person really would not be protected in the intermediate country, then it is a violation of international law to convict someone who aids the refugee. And Canadian law must, if possible, be interpreted to be consistent with international law.

A person helping a refugee coming directly from a country where his life or freedom would be threatened has an additional defence as well. The Refugee Convention prohibits the imposition of penalties on refugees on account of their illegal entry or presence. The refugees must come directly from a territory where their life or freedom was threatened. They must present themselves without delay to the authorities. 
Because penalties for illegal entry or presence are a violation of the Convention, penalizing those who aid illegal aliens would also violate the Convention. At the time the Refugee Convention was being drafted, the Swiss representative to the Ad Hoc Committee of the Economic and Social Council of the United Nations, established to draft the Convention, drew the attention of the Committee to a provision of Swiss law. That provision stated that a person who aids a refugee enter the country illegally is not subject to punishment if he or she acted our of honourable motives. The Ad Hoc Committee did not include in its draft a provision specifically referring to those who assist to secure the illegal entry or presence of refugees, but several delegates, including the American, Mr. Henkin, expressed the hope that "Governments would take note of the very liberal outlook embodied in the Swiss federal laws and follow that example".

For a Canadian Sanctuary movement to be able to take advantage of this provision of the Convention, the refugee most have presented himself without delay to the authorities. "Without delay" does not necessarily mean immediately. If the time between entry and presentment is reasonable in the circumstances, there is no delay. Presentment need not even be voluntary. A refugee can come within this provision even if he is apprehended before he or she has had a chance to give himself or herself up. It is the time element that is important when invoking this Convention provision.

Because the refugee must have come directly from the country where his or her life or freedom was threatened in order for a Sanctuary defendant to invoke this defence,the defence is of little use to those aiding refuges who have come from an intermediate country. But other defences are open.

There is a defence open to a potential Sanctuary defendant in Canada, a defence that is part of international law and is also part of the ordinary Canadian civil law. Its is the defence of necessity as it exists in international law.

The domestic defence of necessity may be described in this way. A defendant in a criminal case may be acquitted, even if he committed proscribed acts with the requisite state of mind, if he did so in the reasonable belief that his conduct was necessary to prevent some greater harm to himself or others. What a Canadian

Sanctuary movement might argue is that what they did was done out of a reasonable belief that their conduct directly preverited bodily harm to refugees.

The prosecution, no doubt, would argue that the accused could not invoke the necessity defence because there exists a detailed administrative and legal process for reviewing a person's claim that he or she is entitled to refuge. The prescribed statutory process can result in claimants obtaining lawful refugee status.

This sort of argument, however, confuses formalism with reality. There is a refugee determination procedure. But the reality is that refugees passing through

... the Sanctuary

movement, by giving the refugees sanctuary, is helping Canada conform to its international obligations towards
refugees.

listed intermediary countries will not be given protection.

What a judge has to decide in a Sanctuary case is not whether the accused are exonerated by the necessity defence, but only whether the jury could consider the necessity defence. In a number of U.S. protest cases, where the judge left the necessity defence to the jury, the accused were acquitted. That was true in cases about accused protesting military air to El Salvador, deprivations of human rights in South Africa, Navy participation in nuclear weapons proliferation, CIA recruiting at the University of Massachusetts. The protests themselves involved some form of illegality, typically trespass.

In protest cases, the necessity defence is a good deal more tenuous than it would be in a Sanctuary case. For, in protest cases, the linkage between the protest and the harm to be prevented is a good deal more remote. Protest has only a specula tive and uncertain link with ending military aid to El Salvador, human rights deprivations in South Africa and so on. What a Sanctuary movement does to protect refugees is direct and effective. The movement would not just protest the failure of the Canadian Covernment to provide protection to refugees. The movement would provide the very pro. tection the government failed to give. The movement would not just influence the avoidance of the greater harm. It actually would go about ensuring the avoidance of the greater harm. So the likelihood of the necessity defence being left to a jury is even greater than in the protest cases.

There is a second defence that a Sanctuary movement could raise that is based both on international law and Canadian domestic law, the defence of religion.

Freedom of religion is both an international standard and a domestic Canadian standand. Freedom or religion is guaranteed by the Universal Declaration of Human Rights, the International Covenant on Civil and Political Rights, which Canada has signed and ratified, the UN Declaration on Religious Intolerance, and the Final Act of the Conference on Security and Cooperation in Europe (the Helsinki Accord). It is also guaranteed by the Canadian Constitution.

Freedom of religion is not just freedom of conscience or belief. It is also freedom to practice one's religion. Religion is not just prayer. It is charity. Religion is not just piety. It is helping people. To the clengy, every human being is made in the image of God. Promoting human rights is doing God's work.

Helping refugees is part of the ministry of a Sanctuary clengy. It has to be considered as part of their religious duties. The Sanctuary concern for refugees is a human rights concern. Sanctuary is offered so that refugees can avoid being forcibly returned and subjected to human rights violations at home. The Sanctuary movement is a movement in defence of human rights. Prosecution of the Sanctuary movement makes the religious work, the practice of the religions of the Sanctuary clergy more difficult.

By prosecuting a Sanctuary movement, the State turns respect for freedom of religion into a formality. A Sancturary movement is not able, because of the pros- 
ecution, to enjoy fully the freedom of religion supposedly guaranteed to it.

Freedom of religion does not allow for derogation from human rights standards. Like all the freedoms, freedom of religion is not an absolute. Practices such as mutilation, amputations, female circumcision, or stoning are not justifiable simply because they are religious practices. Sexual discrimination, discrimination against women, is not acceptable by international standards because it is condoned by religion.

The situation is altogether different when religion is promoting human rights. The human rights standards and freedom of religion go hand-in-hand. They each reinforce the other. Respect for human rights is a value in itself. When both the human rights of refugees and freedom of religion are thwarted, the violation of international standards is doubly heinous.

There is a second provision of the Charter that is relevant in assessing the legal worth of a Sanctuary defence. That the rights of life, liberty and security of the person not be denied, except in accordance with the principles of fundamental justice. It can be argued that, when a Sanctuary defendant is prosecuted in violation of international law, the fundamental justice is denied.

The Canadian Charter of Rights and Freedoms is subject to the supremacy of God and the rule of law. These are two guiding principles stated at the beginning of the Charter. When the rule of law is violated, then fundamental justice is denied.

The rule of law does not mean that the law is obeyed. The rule of law is a standard or test by which laws themselves can be assessed. Laws can violate the rule of law.

The rule of law means that laws are not applied arbitrarily. Laws are applied equally to all. It is a violation of the rule of law to apply to an individual only the inculpatory provisions, and not also the exculpatory provisions of the law.

For instance, in the law of murder, if the Defender (D) defends the Victim (V) the Perpetrator $(P)$ is trying to murder, and in the process uses force against $P, D$ can claim the right of private defence. It would be absurd to prosecute $D$ for his assault on $P$ without any regard for the fact that $P$ was trying to murder $V$. Indeed, the law does not allow for it. $D$ is justified in using reasonable force in the defence of $V$, because there is a general liberty as between strangers to prevent an offence.

This was very much like what would be happening at a Sanctuary trial. The refugees are the victims. The accused are the defenders. The Canadian authorities, by denying protection, are the perpetrators. The accused, in order to protect the victims, would be violating what the perpetrators claim to be their rights.

These principles hold true for international human rights law. If a person commits an act that would otherwise be contrary to domestic law in an attempt to bring his country into compliance with

\section{The Canadian} Government, by prosecuting the individuals who provide sanctuary, would be in violation of its international obligations.

international law, then it is a violation of the rule of law to prosecute the person for his act. It is absurd to look at the alleged domestic offence in abstraction from the requirements of international law. If Sanctuary defendants were to be prosecuted for a domestic offence, in abstraction from an international law stating that refugees must not be returned to a country where their life or freedom would be threatened, then one law would be applied, the domestic law on illegal immigrants. Another law would be ignored, the international law of refugees. In that situation, the rule of law would be mocked and abandoned, and fundamental justice denied.

That is all I have to say about Canadian law, but is it not all I have to say about the law. Even if Canadian law could lead to a conviction, there is an additional international law perspective.

International law limits the obliga-

tions individuals owe states. International obligations binding upon individuals must be carried out, even if to do so violates a positive law or directive of the state. Once a person is free to choose to violate international law or comply with international law, he is personally responsible for the choice. Anyone with knowledge of illegal activity and an opportunity to do something about it is a potential criminal under international law unless the person takes affirmative action to prevent the commission of the crime. Because individuals are responsible for their nation's conduct at international law, individuals must act to repudiate that conduct, if it is possible for them to do so.

This defence, based on international law, is a second onder defence. It requires a prior finding of breach of international law. State illegality justifies individual violations of state directives. But is state activity illegal? In a Sanctuary case, the state activity would be illegal, because of forcible return of refugees to intermediate countries whether they would be protected there or not.

This defence assumes that what the accused did was illegal according to Canadian law. The action becomes illegal only under another different law, put against Canadian law, namely, international law.

There must be some nexus between the local law disobeyed and the local law violating international standards. Disobedience of the law that leads to prosecution must itself manifest a refusal to participate in the conduct that violates international standards.

That would certainly be the situation of a Sanctuary movement. A Sanctuary movement would not simply be violating an extraneous law in order to protest Canadian violation of international refugee law. A Sanctuary movement would violate the very law that in turn violated international standards.

David Matas, a Winnipeg lawyer, has been acting as Legal Counsel to the League for Human Rights of B'nai Brith Canade and as co-ordinator of the legal network of AI-CS (ES). This article is an edited persion of his remarks at the "Called to Respond: Refugees and the New Canadian Reality" conference of the Canadian Jesuit Refugee Programme at Niagara Falls, Ontario, on October 29, 1988. 